\title{
INTERNALISASI KARAKTER BERSYUKUR UNTUK MENINGKATKAN MOTIVASI BELAJAR SISWA
}

\author{
Ishmatun Nihayah \\ Institut Pesantren KH Abdul Chalim Mojokerto \\ Email: ishmahnihayah@gmail.com \\ Fina Surya Anggraini \\ Institut Pesantren KH Abdul Chalim Mojokerto
}

\begin{abstract}
Abstrak
Pendidikan di Indonesia memerlukan generasi penerus yang cerdas. Bukan hanya sekedar cerdas secara akademik namun juga secara spiritual. Oleh karena itu membutuhkan yang namanaya pendidikan karakter. Salah satu karakter yang perlu ditanamkan adalah karakter bersyukur. karena syukur bukan sekedar ucapan belaka, namun juga tindakan nyata. Penelitian ini merupakan penelitian kualitatif dengan menggunakan metode library reseach, dimana peneliti mencari sumber dan data melaui buku-buku dan jurnal-jurnal yang sesuai dengan judul diatas. Hasilnya ada berbagai macam penelitian yang telah memaparkan manfaat dari bersyukur, salah satu karakter religius yang dapat membuat kebermaknaan dalam hidup dan menghasilkan perubahan berfikir pada peserta didik apabila disentuh aspek - aspek tertentu. Dengan menghayati siapa dirinya lewat bersyukur ini peserta didik akan termotivasi untuk belajar. Karena dengan pendekatan bersyukur ini dia akan terpacu agar tidak kufur terhadap nikmat yang telah diberikan. Penanaman karakter merupakan sebuah proses yang memerlukan waktu cukup panjang. Oleh sebab itu cara yang mudah adalah melalui pendidikan. Baik itu pendidikan formal maupun informal.
\end{abstract}

\section{PENDAHULUAN}

\section{A. Latar Belakang}

Perkembangan jaman yang semakin modern terutama pada era globalisasi menuntut adanya sumber daya manusia yang berkualitas tinggi. Peningkatan kualitas sumber daya manusia adalah mutlak untuk mencapai tujuan pembangunan. Salah satu cara dalam mengupgrade kualitas sumber daya manusia tersebut adalah dengan adanya Pendidikan. Pendidikan merupakan usaha sadar dan sistematis untuk menumbuh kembangkan potensi sumber daya manusia melalui kegiatan pengajaran. Dalam Undang-Undang Sistem Pendidikan Nasional No. 20 tahun 2003, menyatakan 
bahwa tujuan pendidikan nasional adalah mencerdaskan kehidupan bangsa dan mengembangkan manusia Indonesia seutuhnya yaitu manusia yang bertakwa terhadap Tuhan Yang Maha Esa dan berbudi pekerti luhur, memiliki pengetahuan dan keterampilan, kesehatan jasmani dan rohani, kepribadian yang mantap dan mandiri serta tanggung jawab kemasyarakatan dan kebangsaan (UU Sisdiknas: 2003).

Untuk menjadi bangsa yang cerdas, maka tidak cukup hanya secara sumber daya saja namun juga perlu berkarakter. Begitu pentinya pendidikan karakter di Indonesia sekarang ini dapat dilihat dari bagaimana gambaran situasi keadaan dunia pendidikan di Indonesia dapat menjadi motivasi pokok pengembangan implementasi pendidikan karakter di Indonesia. Bidang psikologi khususnya, dalam kajian psikologi yang positif saat ini mulai menjadi perhatian para ahli psikologi dalam mengungkapkan serta memecahkan masalah-masalah sosial yang tumbuh dan berkembang di tengah masyarakat serta membantu manusia mencapai kebahagiaan melalui emosi emosi positif. Syukur adalah salah satu dari kajian psikologi positif tersebut, yang berarti mengucapkan terima kasih atas anugerah kepada yang telah memberi. Syukur tidak cukup hanya dilisan saja namun harus dilakukan dengan tiga hal, yaitu lisan, hati, dan anggota badan sebagaimana iman. Dalam pandangan Islam, orang yang bersyukur kepada Allah Swt. atas kenikmatan yang diterima, maka ia harus mengakui kenikmatan itu dalam hatinya, kemudian lisannya mengucapkan kalimat syukur (alhamdulillah) atau memberitahukannya kepada orang lain, dan anggota badannya tergerak untuk lebih taat beribadah kepada Allah Swt. Dan memberikan sebagian kenikmatan itu kepada orang lain yang membutuhkan.

Penelitian yang dialakukan Sheldon dan Sonja menunjukkan bahwa kebersyukuran dapat mengurangi emosi negatif (buruk) pada diri seseorang. Begitu juga dengan Romdhon mengatakan bahwa orang yang bersyukur akan mudah mencapai kebahagiaan dan kehidupan yang penuh ketentraman dengan begitu akan lebih terhindar dari keadaan yang menekan (stressfull) serta mudah dalam menghadapi berbagai permasalahan hidup. Syukur juga mampu membuat individu tidak mudah merasa kesepian dan terhindar dari gejala serta rasa depresi. 
Dari sini dapat penanaman karakter bersukur bisa menjadi solusi ditengah kurang termotivasinya anak dalam kegiatan pembelajaranya. Dengan menyentuh pola pikir dari anak dari yang malas dapat menyebabkan berubahnya tingkah laku serta mindset dalam belajarnya ${ }^{1}$. Pada pembahasan ini akan dijelaskan apakah memang benar karakter syukur mempunyai hubungan dengan motivasi belajar anak, dari uruaian tersebut mungkin dapat lebih dikembangkan dimasa mendatang sebagai salah satu alternativ pemecahan masalah motivasi belajar.

\section{PEMBAHASAN}

\section{A. Teori dari Internalisasi, Karakter, Bersukur, dan Motivasi Belajar}

\section{Internalisasi}

Pengertian internalisasi di ungkapkan oleh Abkamaliyani (2013: 6), bahwa internalisasi adalah": "Pembinaan secara sungguh-sungguh tentang nilai-nilai religius yang dicampur dengan nilai-nilai pendidikan secara utuh yang sasarnnya adalah agar menyatu didalam kepribadian peserta didik, sehingga menghasilkan satu karakter atau tabiat bagi peserta didik tersebut". Dengan adanya pertumbuhan dan perkembangan yang dialami dan dilalui oleh setiap manusia, maka menyebabkan selalu terjadi proses internalisasi yang berjalan sesuai dengan tugas-tugas perkembangannya. Internalisasi secara etimologis dapat didefinisikan sebagai suatu proses. Proses internalisasi sebenarnya telah terjadi sejak seorang individu itu lahir ke dunia atau sejak awal kehidupan sampai akhir hayatnya. Internalisasi dapat diartikan juga sebagai proses penanaman dan menumbuh kembangkan suatu nilai atau budaya tertentu melalui suatu penghayatan, pendalaman, serta penguasaan secara mendalam yang berlangsung melalui bimbingan serta binaan agar karakter tesebut tertanam secara kuat dalam diri individu.

\section{Karakter}

${ }^{1}$ Muhammad Anas Ma`arif dan Muhammad Husnur Rofiq, "The Role of Islamic Education Teachers in Improving the Character of Nationalism in Boarding School," EDUKASI: Jurnal Pendidikan Islam 6, no. 1 (21 Juni 2018): 064-078, https://doi.org/10.5281/edukasi.v6i1.323.

2 Abidinsyah, "Internalisasi Nilai Peduli Lingkungan Melalui Pembelajaran Berbasis Kearifan Lokal: Studi Di Sdn Antasan Besar 7 Banjarmasin” (phd, Universitas Pendidikan Indonesia, 2013), http://repository.upi.edu/3700/10/D_PU_0908541_Appendix.pdf. 
Secara bahasa 'karakter' diartikan sebagai sifat manusia pada umumnya yang bergantung pada faktor kehidupannya sendiri. Menurut Hidayatullah (2010:9) menjelaskan bahwa secara lafaldz 'karakter' adalah kualitas atau kekuatan mental atau moral, akhlak atau budi pekerti seseorang yang merupakan kepribadian khusus yang membedakan dengan orang lain. Menurut kamus lengkap Bahasa Indonesia (Tim Bahasa Pustaka Agung Harapan, 2003:300), karakter adalah sifat-sifat kejiwaan, akhlak, budi pekerti yang membedakan seseorang dari yang lain, tabiat, watak. Maskawih (1994:56) berpendapat bahwa karakter merupakan keadaan dair suatu jiwa. Keadaan ini menyebabkan ketika jiwa bertindak maka tanpa dipikir atau dipertimbangkan secara mendalam. Menurut Lickona (2004), secara substantif terdapat tiga unjuk perilaku yang satu sama lain saling berkaitan yaitu konsep moral (moral knonwing), sikap moral (moral feeling), dan perilaku moral (moral behavior).

Berdasarkan ketiga komponen ini dapat dinyatakan bahwa karakter yang baik didukung oleh pengetahuan tentang kebaikan, keinginan untuk berbuat baik, dan melakukan perbuatan kebaikan. Koesoema (2007:80) menjelaskan karakter sama dengan kepribadian. Kepribadian dianggap sebagai ciri atau karakteristik atau gaya atau sifat khas dari diri seseorang yang bersumber dari bentukan-bentukan yang diterima dari lingkungan, contohnya keluarga pada masa kecil, dapat juga bawaan sejak lahir. Sementara Winnie (dalam Koesoema, 2007:80) berpendapat bahwa istilah karakter memiliki dua pengertian. Pertama, ia menunjukkan bagaimana seseorang bertingkah laku dalam kesehariannya. Apabila seseorang tersebut berperilaku tidak jujur, kejam, atau rakus, tentulah orang tersebut memanifestasikan perilaku buruk dari tingkah lakunya sehari- hari tersebut. Sebaliknya apabila seseorang berperilaku jujur, suka menolong sebagai contoh, maka sudah tentu orang tersebut memanifestasikan karakter mulia. Kedua, istilah karakter erat kaitannya dengan personality (keseseorangan).

Disini seseorang baru bisa disebut orang yang berkarakter (a person of character) apabila tingkah lakunya tidak menyimpang dari kaidah- kaidah moral. Karakter dan kepribadian sering digunakan secara campur aduk. Ada yang menyamakan diantara keduanya. Kepribadian menunjuk pada organisasi dari sikap- 
sikap seseorang untuk berbaur, mengetahui, berpikir, dan merasakan khususnya, apabila dia berhubungan dengan orang lain atau menanggapi suatu keadaan ${ }^{3}$. Kepribadian merupakan hasil abstraksi dari individu dan perilakunya serta masyarakat dan kebudayaannya. Jadi ketiga aspek tersebut mempunyai hubungan yang saling mempengaruhi. Orang yang disebut berkarakter adalah orang yang dapat merespon segala situasi secara bermoral, yang memanifestasikan dalam bentuk tindakan nyata melalui tingkah laku yang baik. Dengan demikian karakter merupakan nilai-nilai yang tertancap dalam diri seseorang melalui pendidikan dan pengalaman dalam hidupnya yang menjadi nilai instrinsik yang melandasi sikap dan perilakunya dalam bertindak.

Dari penjelasan di atas dapat disimpulkan bahwa karakter merupakan suatu aplikasi nilai-nilai, kebiasaan dan perilaku yang diwujudkan dalam bentuk tindakan yang relatif stabil dan terus menerus dan dalam hubungannya dengan lingkungan tidak menyimpang.

\section{Bersyukur}

Kebersyukuran dalam bahasa Inggris disebut gratitude. Kata gratitude diambil dari akar bahasa Latin yaitu gratia, yang berarti kelembutan, kebaikan hati, atau berterima kasih. semua kata yang terbentuk dari akar Latin ini berhubungan erat dengan kebaikan, kedermawanan, pemberian, keindahan dari memberi dan menerima, atau mendapatkan sesuatu tanpa tujuan apapun (Pruyer; Emmons \& McCullough, 2003). Menurut Emmons dan McCullough (2003) dalam Sulistyar ini (2010), menunjukkan bahwa kebersyukuran merupakan sebuah bentuk perasaan atau emosi, yang kemudian berkembang menjadi suatu sikap, kemudian menjadi sifat moral yang baik, menjadi kebiasaan, menghasilkan sifat kepribadian, dan akhirnya akan mempengaruhi seseorang menanggapi/bereaksi terhadap sesuatu atau situasi. Emmons juga menambahkan bahwa syukur itu membahagiakan,membuat perasaan nyaman, dan bahkan dapat memacu motivasi.

\footnotetext{
${ }^{3}$ Muhammad Anas Ma'arif, “Analisis Konsep Kompetensi Kepribadian Guru PAI Menurut AzZarnuji," ISTAWA 2, no. 2 (2017): 35-60.
} 
Beberapa tokoh psikologi dalam Seligman dan Peterson (2004) mendefinisikan Gratitude atau syukur sebagai suatu perasaan terima kasih dan menyenangkan atas respon penerimaan hadiah, dimana hadiah itu memberikan manfaat dari seseorang atau suatu peristiwa yang memberikan kedamaian. Menurut Wood (2009), menyatakan kebersyukuran adalah sebagai bentuk ciri pribadi yang berpikir positif serta mempresentasikan hidup menjadi lebih positif. Syukur menempati kedudukan yang tinggi di antara sifat-sifat terpuji lainnya. Bahkan alGhazali menempatkan syukur pada kedudukan yang lebih tinggi di atas sabar, zuhud, dan sifat-sifat lainnya Kebersyukuran dapat diwujudkan dalam sebuah pujian kepada sumber yang memberi atau dengan mengucapkan terima kasih. Bersyukur menjadi salah satu dari lima karakter yang paling menonjol dibanding karakter kekuatan lainnya (Arbiyah, Imelda dan Oriza, 2008). Jadi, berdasarkan beberapa pengertian para ahli maka dapat disimpulkan bahwa syukur dalam konsep barat gratitude atau kebersyukuran adalah pengakuan seseorang tentang adanya pihak lain atau sumber yang turut andil atas nikmat yang diterima, oleh karena itu kebersyukuran dapat mendorong seseorang untuk memberikan pujian atau memberikan ucapan terima kasih pada pihak yang telah berbuat baik.

\section{Motivasi Belajar}

Motivasi merupakan pendorongan yaitu suatu usaha yang disadari untuk mempengaruhi tingkah laku seorang individu agar ia tergerak hatinya untuk bertindak melakukan sesuatu sehingga mencapai suatu hasil atau tujuan tertentu ${ }^{4}$. (Ngalim Purwanto, 2006: 71). Menurut Oemar Hamalik (2001: 158) motivasi merupakan perubahan energi dalam diri pribadi seseorang yang ditandai dengan timbulnya perasaan dan reaksi untuk mencapai tujua. Motivasi belajar sendiri menurut Sardiman (2007: 75) adalah keseluruhan daya penggerak di dalam diri siswa yang menimbulkan kegiatan-kegiatan belajar, yang menjamin kelangsungan dari kegiatan belajar dan yang memberikan arah pada kegiatan belajar, sehingga tujuan yang dikehendaki oleh subjek belajar itu dapat tercapai.

\footnotetext{
${ }^{4}$ Muhammad Anas Ma`arif dan Salamatu Rochmah, "Target Hafalan Sebagai Motivasi Belajar Dalam Membentuk Karakter Di Lingkungan Pesantren,” Muróbbî: Jurnal Ilmu Pendidikan 2, no. 1 (13 Agustus 2018): 105-27.
} 


\section{B. Hubungan antara dari Internalisasi, Karakter, Bersukur, dan Motivasi Belajar}

Seperti yang telah dipaparkan bahwa internalisasi adalah proses penanaman dan menumbuh kembangkan suatu nilai tertentu yang berlangsung melalui bimbingan serta binaan, maka penanaman inilah merupakan awal dari proses timbulnya nilai. Target nilainya adalah tumbuhnya karakter bersyukur peserta didik, dampak dari perasaan bersyukur dapat berkembang menjadi reaksi atau bahkan tanggapan yang berwujud dalam bentuk sikap. Oleh karena itu syukur dapat mendorong dan memotivasi seseorang. Bentuk respon dari kebersyukuran sendiri nampak dalam komponen-komponen kebersyukuran seperti apresiasi, goodwill, dan bertindak positif. Ahli pskologi barat Fitzgerald dalam Lopez dan Snyder (2004) mengemukakan komponen dalam bersyukur yaitu :

a. Rasa apresiasi yang hangat kepada orang lain atau sesuatu meliputi rasa cinta dan kasih sayang

b. Niat baik yang ditunjukan pada seseorang atau sesuatu, meliputi keinginan membantu orang lain yang sedang dalam kesusahan, keinginan untuk berbagi dll.

Dari kedua komponen tersebut saling berkaitan, antara apresiasi dan niat baik dapat mencerminkan perilaku seseorang. Ketika apresiasi dengan rasa cinta disertai niat baik digunakan untuk hal yang positif, tentunya dapat menambah gairah. Targetnya adalah motivasi belajar anak yang ditingkatkan. Dalam menginternalisasikan Karakter bersukur, ada beberapa aspek yang perlu dimunculkan dalam benak peserta didik. Al-Munajjid dalam Sulistyarini (2010) menjelaskan tiga aspek diantaranya :

a. Mengenal nikmat

Menghadirkan dalam hati, meyakinkan dan menyadari bahwa segala sesuatu dan keajaiban yng kita miliki dan lalui merupakan nikmat Allah SWT

b. Menerima nikmat

Menyebutnya dengan memperlihatkan kefakiran kepada yang memberi nikmat dan hajat kita kepada-Nya, karena memahami bahwa nikmat itu bukan karena 
keberhakan kita mendapatkannya akan tetapi karena itu bentuk karunia dan kemurahan Tuhan.

c. Memuji Allah atas pemberian nikmat

Pujian yang berkaitan dengan nikmat itu ada 2 macam, yang pertama bersifat umum yaitu dengan memujinya bersifat dermawan, pemurah, baik, luas pemberiannya dan sebagainya. Sedangkan yang kedua adalah bersifat khusus yaitumembicarakan nikmat yang diterima itu dengan merinci nikmat - nikmat tersebut lalu mengungkapkan dengan lisan dan menggunakan nikmat tersebut untuk hal -hal yang diridhainya.

Dengan menyentuh ketiga aspek tersebut dimulai dari mengenal, yaitu peserta didik diajak untuk menghadirkan nikmat itu seperti apa kemudian dimasukan kedalam hati mereka, dengan penguatan memuji kepada Allah, maka akan merasakan kebermaknaan hidup. Kebermaknaan hidup didefinisikan sebagai keadaan penghayatan hidup yang dipenuhi dengan makna yang membuat individu dapat merasakan hidupnya lebih berharga, lebih bahagia, serta memiliki tujuan yang akan dipenuhinya untuk masa yang akan datang, hal ini dipaparkan oleh (Frankl, 1977; Koeswara, 1992;Bastaman, 1996).

Makna hidup merupakan sesuatu yang dianggap penting, benar dan didambakan serta memberikan nilai khusus bagi seseorang. Menurut Frankl (2004) makna hidup bersifat personal dan unik. Hal ini disebabkan karena individu bebas menentukan caranya sendiri dalam menemukan serta menciptakan makna dalam hidupnya. Jadi, penemuan dan penciptaan makna hidup menjadi tanggung jawab individu itu sendiri serta tidak dapat diserahkan kepada orang lain, karena hanya individu itu sendirilah yang mampu merasakan dan mengalami makna dalam hidupnya.

Jika keadaan hidup seseorang tidak memiliki makna, dan hal ini terjadi pada diri individu secara berlarut -larut, maka akan menimbulkan gangguan psikis, atau bahkan simptom yang dinamakan sebagai neurosis noogenik . Individu juga akan 
kehilangan minat terhadap kegiatan yang sebelumnya baginya itu menarik, selain itu akan mengalami hilangnya inisiatif, merasa hidup tidak ada lagi artinya, menjalani hidup seperti tanpa tujuan yang jelas. Keadaan ini secara kasat mata seperti gangguan depresif, akan tetapi pengobatan dengan anti -depresan yang secara medis tidak mampu menghapusnya.

Bisa kita ambil kesimpulan dari pendapat Frankl bahwasanya makna hidup adalah sesuatu yang dianggap urgen karena memberikan nilai khusus bagi seseorang yang apabila telah terpenuhi, akan membuat seseorang merasakan lebih berharga, bahagia serta memiliki tujuan yang mulia untuk dipenuhi. Tetapi sebaliknya, apabila tidak terpenuhi, maka seorang individu akan merasa bahwa hidupnya itu tidak bermakna. Setiap orang bisa menemukan dan memiliki makna hidup dalam setiap keadaan dan waktu yang berbeda - beda. Dengan menggunakan kebersyukuran, diharapkan peserta didik bisa mengalami kebermaknaan hidup agar dalam hidupnya seperti yang dipaparkan tadi.

Dari kebermaknaan hidup ini dapat diarahkan agar pola pikir siswa yang kurang termotivasi belajar dapat berubah menjadi semangat. Karena akal, sebagai potensi berpikir, yang dimiliki oleh manusia telah menjadikannya berbeda dari makhluk lain. Manusia tidak hanya menjadi bagian dari alam, dan hanya hidup diantara makhluk lain di bumi, akan tetapi, dengan menggunakan kemampuan berpikirnya tersebut, manusia dapat menyadari makna kehidupannya, sehingga dengan cara tersebut ia mampu mengarahkan proses hidupnya sendiri dan tidak hanyut dalam proses kehidupan alamiahnya semata. Dengan akalnya manusia berupaya memahami alamnya, memahami makna kehidupannya dan makna keberadaanya diantara benda-benda alam dan makhluk hidup selain dirinya. Dengan pemikiran dan pemahamannya tentang alam, kehidupan dan makna keberadaan dirinya tersebut, manusia memiliki konsep-konsep tentang nilai-nilai dan pandangan tentang dunianya dan kehidupanyya.

Dengan pikirannya, manusia memiliki thought style. Istilah thought style (pola pikir), dipopulerkan oleh Karl Mannheim dalam bukunya Ideology and Utopia (Fuad 
Baali dan Ali Wardi, 1981; 22). Dalam bahasa aslinya yang digunakan Mannheim, pola pikir adalah denkstil, yang kemudian diterjemahkan ke dalam bahasa asing yaitu bahasa Inggris yang menjadi thought style, dengan mempunyai arti kebahasaan sama yaitu pola pikir. Pola pikir yang dimaksud di sini adalah prakonsepsi-prakonsepsi atau kategori-kategori yang implisit, yang membentuk kerangka acuan atau perspektif, darimana seseorang memandang dunia, yang kemudian menghasilkan kecenderungan dalam menbentuk sikap mental, pandangan hidup atau falsafah dalam hidup (Fuad Baali; 22).

Dari terciptanya pola pikir yang semakin maju kedepan, maka akan timbul kesadaran diri. Chmanto Mendatu (2010), mengemukakan kesadaran diri merupakan keadaan dimana seseorang dapat memahami bagaimana dirinya sendiri dengan setepat - tepatnya. Seseorang dapat disebut mempunyai kesadaran diri apabila individu tersebut memahami emosi dan mood yang sedang dirasakanya, bersikap kritis terhadap informasi mengenai dirinya sendiri, serta sadar tentang dirinya yang nyata. Dessler (1997), mengemukakan arti penting dari sumber daya manusia itu sendiri terhadap organisasi terletak pada kesadaran diri manusia tersebut dalam bereaksi positif terhadap sasaran pekerjaan atau kegiatan yang mengarah pada pencapaian organisasi. Jadi dapat kita pahami bahwa dengan munculnya kesadaran diri, maka seorang individu tahu, siapa dirinya, apa posisinya, apa tugasnya serta harus bagaimana. Oleh karena itu dengan meninternalisasikan kesadaran diri agar menjadi karakter yang melekat pada individu dapat dilakukan melalui rasa syukur.

Dalam prespektif islam Tata cara bersyukur kepada Allah tentu saja tidak hanya dengan sujud syukur dan salat, lebih dari itu kita juga bisa melakukan ibadah apa saja yang diperintahkan oleh Allah, baik berupa amal ibadah mahdhah (khusus) dalam rangka berhubungan baik dengan Allah sebagaimana termaktub dalam rukun Islam, maupun juga ibadah ghairu mahdhah (umum) dalam hubungannya dengan sesama manusia dan alam semesta. Di sini, bersyukur tentu saja juga bisa diekspresikan dengan cara berupaya semaksimal kita untuk menjauhi apa saja yang dilarang oleh Allah ( amar makruf nahi munkar ). 
Secara praktis, ekspresi syukur dapat diwujudkan dengan memanfaatkan segala apa yang kita miliki untuk kebaikan-kebaikan bagi diri, keluarga, masyarakat, bangsa, negara dan orang di sekitar kita. Mata kita untuk melihat yang baik-baik sekaligus membaca dan memahami ayat - ayat kekuasaan Allah. Kaki digunakan untuk berjalan menuju kebaikan. Telinga untuk mendengar yang baik. Hati untuk merasakan, menghayati dan mensyukuri nikmat-Nya. Tidak hanya itu, nikmat sehat yang kita rasakan, misalnya juga bisa kita manfaatkan untuk bekerja dan beribadah dengan sungguh-sungguh. Nikmat harta yang kita punya, bisa kita manfaatkan untuk saling berbagi, berinfak dan beramal jariyah untuk tabungan dan investasi akhirat nanti. Nikmat iman yang kita hayati perlu terus kita syukuri dengan cara berdoa dan berusaha terus menerus berupaya mengamalkan ajaran Islam dengan ikhlas lillahi ta'ala. Hal tersebut dijelaskan dalam Perwujudan rasa syukur Menurut Al - Fauzan dalam Sulistyarini (2010) mengatakan bahwa orang yang bersyukur, menggunakan lidah, hati dan anggota badannya untuk mencintai Allah, tunduk pada - Nya, dan menggunakan nikmat - nikmat - Nya di jalan yang di Ridhai -Nya.

Ada beberapa hasil penelitian tentang pengaruh ekspresi syukur ketika telah dipraktikkan seseorang terhadap kesuksesan dalam kehidupannya. Pertama, syukur bisa membawa prestasi belajarnya anak sekolah bertambah bagus. Beberapa hasil penelitian telah menunjukkan bahwa ekspresi dari anak yang berprestasi dalam sekolahnya bisa dilihat dari aktivitasnya di dunia maya dalam media sosialnya. Ratarata ditemukan bahwasanya anak yang mempunyai prestasi di sekolah, khususnya di Indonesia, anak yang menggunakan jejaring sosial, misalnya Facebook, twitter dsb ternyata menuliskan statusnya tersebut menggunakan kata-kata yang positif dan dengan ungkapan syukur dapat membuat anak tersebut lebih berprestasi serta lebih cepat dewasa dalam berpikir serta juga belajarnya. Hal berbeda sebaliknya dengan anak sekolah yangu aktif menulis di Facebook-nya atau media sosial yang lain tersebut dengan kata- kata keluhan, kegalauan dan kata-kata negatif lainnya, siswa tersebut lebih banyak kurang dalam berprestasi. Jadi, patut untuk direnungkan untuk kita semua dalam berkomunikasi dengan orang lain hendaknya berusaha agar 
mengekspresikan diri secara positif. karena ungkapan positif lahir dari perasaan, pikiran dan selanjutnya akan memengaruhi tindakan kita. Ungkapan dan juga perkataan kita merupakan bagian dari doa. maka dari itu, dengan berkata yang baik baik, kita sama saja dengan berdoa yang baik juga untuk diri sendiri dan semuanya.

Kedua, syukur dapat membuat kita lebih bahagia. karena Semakin kita sering berekspresi syukur otomatis juga semakin kita bahagia. Dalam konteks inilah, dengan syukur bisa membuat kita menjadi senyum. dari senyum tersebut akan membuat kita menjadi lebih bahagia dan senang. Kisah kasih syukur telah tertuang di dalam alQur'an pada surat Luqman ayat 12, yaitu: "Bersyukurlah kepada Allah. Dan barangsiapa yang bersyukur (kepada Allah) maka sesungguhnya ia bersyukur untuk dirinya sendiri; dan barang siapa yang tidak bersyukur maka sesungguhnya Allah Maha Kaya lagi Maha Terpuji.”

Dari ayat tersebut menunjukan bahwasanya syukur yang telah kita lakukan akan membawa keberuntungan terutama pada diri kita. Ada juga hasil penelitian yang beraal dari Amerika Serikat yang dilakukan Robert A. Emmons, Ph.D., dari University of California, mengenai dampak positif dari bersyukur. Menurutnya, bersyukur dapat membuat seseorang merasakan lebih bahagia dan tidak mudah depresi. Seperti dikutip juga dari Arien Haryadi dalam web pribadinya, riset ini membuktikan bila bersyukur secara teratur bisa meningkatkan kebahagiaan, kesehatan, hingga mood,. Bahkan, rasa bersyukur juga bisa membawa dampak yang luar biasa juga dari segi fisik, psikologi serta sosial.

Ketiga, syukur membuat kita menjadi kaya. kita dapat menrnungkan firman Allah dalam Al-Quran.

”Sesungguhnya jika kamu bersyukur, pasti Kami akan menambah (nikmat) kepadamu dan jika kamu mengingkari (nikmat-Ku) maka sesungguhnya azab-Ku sangat pedih”.(QS. Ibrahim:7).

Ayat tersebut menunjukan secara tegas kepada kita bahwa bila kita semua ingin sukses, bahagia, kaya serta banyak rezekinya maka dengan cara bersyukurlah. 
Sebaliknya, bila kita tidak mau bersyukur maka kita tentu harus bersiap - siap gagal dan juga siap mendapat petaka serta bencana. maka itu, jalan terbaik yang perlu ditempuh tidak lain adalah bersyukur, bersyukur serta bersyukur. Dari sini, bisa dipahami yaitu bersyukur adalah jalan pertama dan utama yang perlu dikerjakan oleh setiap anak manusia yang ingin sukses serta dilipat gandakan rezeki dan nikmatnya. Ayat syukur diatas benar - benar membawa kita pada keadaan sukses lahir dan batin. Hati kita tidak terasa terbebani oleh perasaan malas dan jenuh dalam belajar karena perasaan dan pikiran kita mengakui yang saat ini kita punyai atau yang belum kita punyai adalah kenikmatan dari Allah.

Dalam buku Dahsyatnya Syukur, Syafii Al-Bantanie menerangkan secara sedherhana, betapa syukur memberikan pengaruh yang amat besar bagi pelakunya. karena tidak hanya dimudahkan dari berbagai macam kesulitan, tapi selain itu mendatangkan serta menambah rezeki, mendatangkan kesembuhan dan mengantar ke surga. disini intinya adalah, ia mengungkapkan bahwa syukur mempunyai hikmah yang amat besar. karena di dalamnya terdapat keutamaan-keutamaan yang akan didapatkan oleh pelakunya. Syukur adalah energi yang dahsyat untuk mencapai kesuksesan serta kebahagian hidup di dunia dan di akhirat.

Dengan ditanamkanya rasa syukur, diharapkan peserta didik akan mempunyai power, dengan menyadari bahwa dirinya adalah siswa maka tugas siswa adalah belajar. Apabila tidak mau belajar dengan sungguh - sungguh bisa dikategorikan orang yang tidak mau bersyukur. Guru selain sebagai fasilitator dalam kegiatan pembelajaran yang memegang peranan penting dalam peningkatan kualitas siswa dan prestasi belajar siswa, guru memang benar harus memperhatikan, memikirkan dan sekaligus merencanakan proses pembelajaran yang menarik bagi siswa, agar siswa semangat dalam belajar dan mau terlibat dalam proses pembelajaran, sehingga pembelajaran tersebut menjadi efektif, namun juga perlu menanamkan motivasi belajar salah satunya dengan kebersyukuran. Seseorang yang mempunyai motivasi tinggi akan melakukan sesuatu dengan penuh semangat, terarah dan penuh rasa percaya diri. Hal ini tentunya berlaku juga pada kegiatan belajar peserta didik. peserta 
didik yang mempunyai motivasi belajar yang tinggi maka akan lebih bersemangat dalam kegiatan belajarnya, dengan semangat tinggi serta bersungguh - sungguh dalam belajar, maka prestasi belajar yang diperoleh akan meningkat lebih optimal lagi. Motivasi belajar merupakan hal yang penting dan perlu diketahui oleh setiap guru dalam peranannya yaitu dapat menumbuhkan gairah, merasa senang dan semangat untuk belajar bagi siswa.

Dari pemaparan diatas dapat kita gambar hubungan dari keepat variabel antara internalisasi, karakter bersyukur dan motivasi belajar siswa.

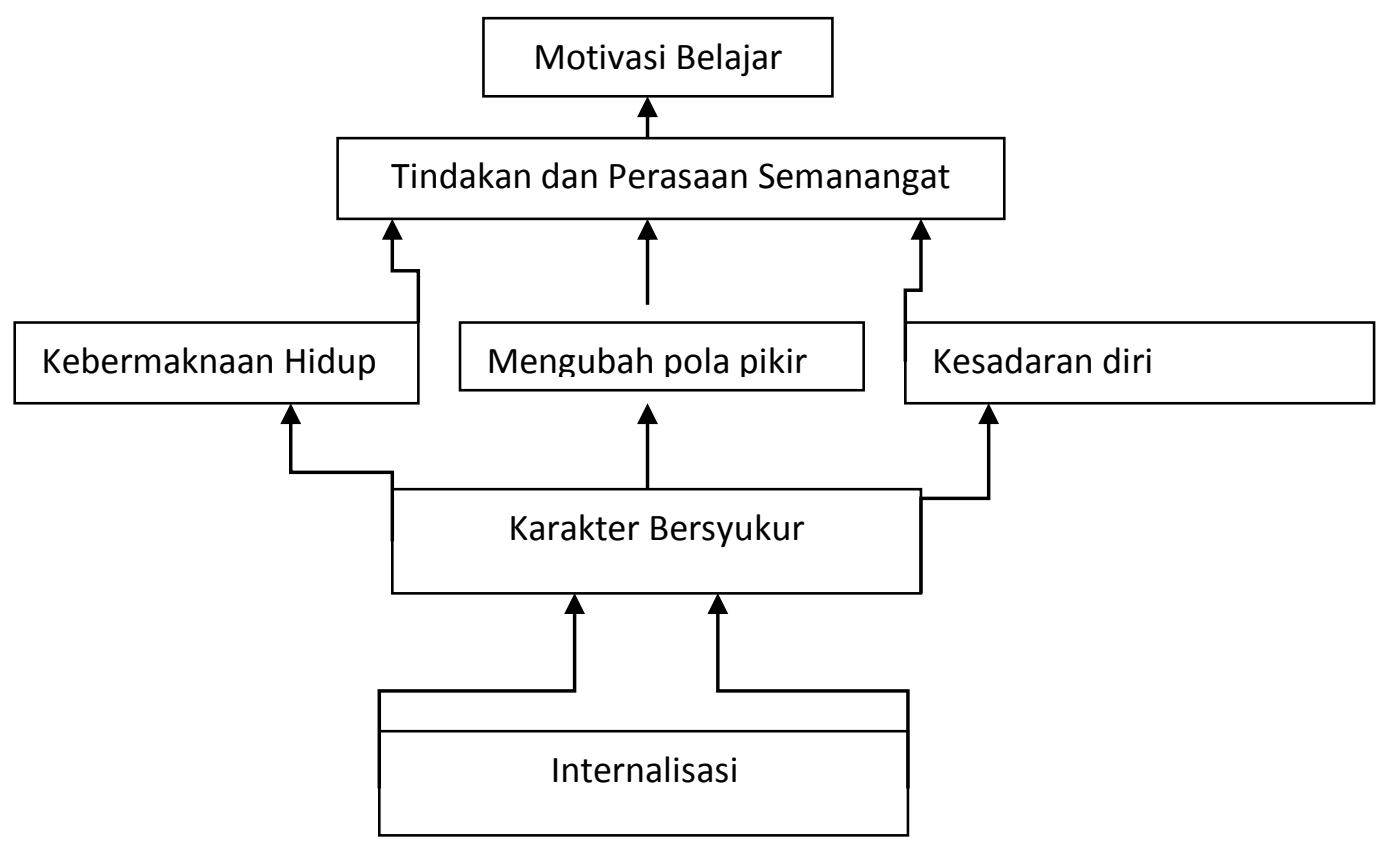

Dari bagan diatas dapat dijelaskan bahwa penginternalisasian karakter bersyukur akan menimbulkan dampak terjadinya karakter peserta didik menjadi ahli 
syukur dengan cara menyentuh beberapa aspek kerohanian yang menimbulkan kebermaknaan hidup, kemudian berubahnya pola pikir dan akibatnya akan timbul kesadaran diri. Setelah sadar akan siapa dirinya dengan karakter syukur tersebut Hidupnya akan ada perasaan senang dan secara otomatis akan melakukan sebuah tindakan yang bermanfaat. Karena disini adalah peserta didik, maka diharapkan peserta didik akan sadar siapa dirinya dan apa tugasnya sehingga melahirkan yang namanya Motivasi belajar. Sebuah motivasi yang berasal dari dirinya sendiri.

Di sini, maksud dari syukur bukanlah kata benda mati. Syukur juga bukan merupakan kata sifat saja. Tapi, syukur merupakan kata kerja yang perlu bukti tindakan nyata sampai akhir hayat kita. Secara lisan, praktik syukur gampang karena bisa dibuktikan dengan mengucapkan kata-kata yang baik sekaligus pujian hanya untuk Allah. Dalam tindakan, syukur ditandai dengan upaya sungguh-sungguh untuk memanfaatkan apa saja yang bisa kita lakukan untuk kemanfaatan dan kemaslahatan semua.

\section{Cara Menginternalisasikan Karakter Bersyukur Untuk Menumbuhkan Motivasi Belajar Siswa.}

Internalisasi pendidikan karakter dapat dilakukan menggunakan berbagai cara, salah satunya adalah dengan menggunakan pendidikan. Pendidikan tersebut antara lain :

a. Pendidikan informal. menurut Syarbini (2012: 64 - 119) dalam rangkumanya menyatakan bahwa metode mendidik karakter anak dirumah dilakukan melalui keteladanan yang diberikan orang orang dewasa atau orang tua kepada anak, mendidik melalui kasih sayang, mendidik melalui curhat, mendidik melalui perhatian, mendidik melalui nasihat, mendidik melalui cerita/ kisah, mendidik melalui pembiasaan, mendidik melalui penghargaan dan hukuman ( punish and reward ). dari poin diatas pedidikan secara informal akan meyebabkan tumbuhnya rasa kekeluargaan yang terjalin antara anak yang pengasuhnya, bisa orang tua maupun orang tua pengganti. dari pendidikan disini anak akan mendapatkan keteladanan dari penglamannya selama dirumah. 


\section{b. Pendidikan Formal}

pendidikan formal bagi anak bertujuan untuk membekali pengalaman berupa teori

- teori ilmu pengetahuan yang akan ia jadikan sebagai pengalaman pada saat ia sudah terlepas dari pengawasan keluarga. meskipun begitu proses internalisasi pendidikan karakter tidak akan berjalan lancar tanpa adanya peran serta dari orang tua, masyarakat maupun pihak sekolah maupun guru. Lewat pendidikan formal ini juga diharapkan anak dapat menerapkan pendidikan karakter yang telah diajarkan di sekolah mereka sendiri - sendiri yang sekiranya bisa mereka terapkan teori tersebut dalam kehidupan sehari - harinya, sehingga kemakarakter bersyukur yang ia miliki juga akan terbantu dengan dilandasi oleh nilai-nilai karakter lainnya.

Pembentukan karakter yang dilakukan di sekolah mempunyai fungsi guna menumbuhkan kesadaran diri ${ }^{5}$. Kesadaran diri adalah proses internalisasi dari informasi dan pengetahuan yang diterima yang pada saatnya, akan menjadi nilainilai yang diyakini kebenarannya serta diwujudkan / diapliksikan menjadi perilaku keseharian anak. maka dari itu, meski kesadaran diri lebih merupakan sebuah sikap, akan tetapi diperlukan juga kecakapan seorang guru untuk menginternalisasi informasi dan pengetahuan tentang karkter bersyukur menjadi nilai-nilai dan kemudian mewujudkannya menjadi perilaku keseharian.

\section{KESIMPULAN}

Pendidikan pada saat ini mengalami berbagai masalah dalam menciptakan generasi penerus bangsa yang cerdas dan berkarakter. hal yang tidak kalah penting sebagai upaya menigkatkan mutu pendidikan adalah dengan belajar. Penanaman karakter bersyukur menjadi salah satu jalan dalam meningkatkan motivasi belajar anak. Hal ini karena ketika anak sudah tertanam suatu karakter dan melekat pada dirinya maka secara otomatis dia akan melakukan sesuatu kebiasaan tersebut dalam kehidupan sehari - harinya secara konsisten. Karakter yang religius bersyukur dapat

5 Muhammad Anas Ma`arif, “Analisis Strategi Pendidikan Karakter Melalui Hukuman Preventif," Ta'allum: Jurnal Pendidikan Islam 6, no. 1 (6 Maret 2018): 31-56, https://doi.org/10.21274/taalum.2018.6.1.31-56. 
menumbuhkan motivasi belajar peserta didik, karena bila dikaitkan dapat diambil benang merah antara bersyukur dengan motivasi belajar. Bersyukur bukan merupakan ucapan lidah belaka, namun didalam hati pun menghayati dan dampak dari penghayatan tersebut realisasinya berupa tindakan.

Dengan meninternalisasikan karakter bersyukur, melalui penanaman yang membutuhkan waktu, karena internalisasi adalah proses bukan hasil. Jadi setelah peserta didik mengerti bersyukur diharapkan mampu menghayati potensi yang dimilikinya dengan skema setelah mengetahui nikmat - nikmat yang dimiliki maka akan mengubah kebiasaanya, dengan cara menyentuh beberapa aspek kerohanian yang akan membuat merasa hidupnya bermakna, kemudian diharapkan pola pikir nya dapat berubah sehingga akan timbul kesadaran diri. Bahwa dirinya adalah seorang peserta didik, maka dengan lewat syukur peserta didik memahami untuk belajar dengan cara sungguh - sungguh, bila tidak sungguh - sungguh merupakan suatu kedhurhakaan kepada nikmat dari tuhan yang telah diberikan kepadanya. Tindakan sungguh - sungguh inilah yang dinamakan motivasi belajar karena melahirkan tindakan yang mendorong kearah positif. Cara menginternalisasikan nilai sendiri bukan sekedar kata - kata manis ataupun olok - olok belaka, melainkan melalui proses berkepanjangan. Salah satunya dengan mengunakan pendidikan. Dapat berupa pendidikan formal maupun informal. Karena keduanya berifat saling melengkapi.

\section{DAFTAR PUSTAKA}

Abkamaliyani, Alya. 2013. Internalisasi Pendidikan Karakter dengan Sarana Kelompok Studi Islam di SMAN 5 Banjarmasin Tahun 2013. E-Jurnal. Diunduh tanggal $2013 \quad$ September http://ejournal.unlam.ac.id/index.php/pkn/search/authors/view?firstName=Alya $\&$ middleName $=\&$ lastName $=$ Abkamaliyani $\&$ affiliation $=$ Universias\%20Lambun $\mathrm{g} \% 20$ 
Al-Bantanie, Syafii. 2009. Dahsyatnya Syukur, Jakarta: Qultum Media.

Arbiyah,N.., F.N. Imelda, dan I.D. Oriza. 2008, “Hubungan Bersyukur Dan

Subjective Well Being Pada Penduduk Miskin”, JPS, Vol. 14, No. 01:11-24.

Berlita, Diyah Ambar.2014. Hubungan Antara Sikap Syukur Dengan Kesejahteraan Subjektif Siswa Man Yogyakarta 1. Skripsi. Program Studi Bimbingan Dan Konseling Jurusan Psikologi Pendidikan Dan Bimbingan Fakultas Ilmu Pendidikan Universitas Negeri Yogyakarta

Dafid, Moch.2012. Hubungan Disiplin Kerja Dengan Kesadaran Dalam Menjalankan Tugas PT. Semen Gresik (Persero) Tbk. Skripsi. Fakultas Psikologi Universitas Islam Negeri Maulana Malik Ibrahim Malang

Febriany, Rani ,dan Yusri . 2013. Hubungan Perhatian Orangtua Dengan Motivasi Belajar Siswa Dalam Mengerjakan Tugas-Tugas Sekolah. Volume 2 Nomor 1 Januari 2013. diambil dari http://ejournal.unp.ac.id/index.php/konselor (26 Mei 2018)

Frankl, Viktor E. 2004. Man's Search For Meaning. Terjemahan Lala Hermawati Dharma. Bandung: Nuansa

Fuad Baali \& Ali Wardi, (1989), Ibnu Khaldun dan Pola Pemikiran Islam, (terj.) Mansuruddin \& Ahmadie Thaha, Jakarta;Pustaka Firdaus, Cet. I.

Gafur , Abdul. 2010. Internalisasi Nilai-Nilai Pendidikan Karakter Dalam Silabus Pendidikan Agama Islam Di Perguruan Tinggi Umum. Diambil dari http://eprints.unsri.ac.id/4055/7/INTERNALISASI_NILAI_pendidikan_karak ter.pdf (22 april 2018)

Hidayatullah, M. Furqon. 2010. Guru Sejati: Pengembangan Insan Berkarakter Kuat Dan Cerdas. Surakarta: Yuma Pustaka.

Haryati, Sri. 2017. Pendidikan Karakter Dalam Kurikulum 2013. Diambil dari: http://lib.untidar.ac.id/wp-content/uploads/2017/01/Pendidikan-Karakter-dalamkurikulum.pdf (23 April 2018)

Koesoemo, Doni. 2010. Pendidikan Karakter:Strategi Mendidik Anak Di Zaman Global. Jakarta: Grasindo 
Lopez, Shane J \& Snyder, C. R. 2004. Positive Psychological Assessment: AHandbook Of Models And Measures. US: American Psychological Association.

Lutviyanti, Novia Irma . 2013. Internalisasi Pendidikan Karakter Dalam Membentuk Kemandirian Anak Di Pondok Asih Sesami Kecamatan Baturetno Kapupaten Wonogiri. Diambil dari : https://core.ac.uk/display/74008472 ( 22 april 2018) Maskawih. 1994. Menuju Kesempurnaan Akhlak. Bandung: Mizan.

Tim Bahasa Pustaka Agung Harapan. 2003. Kamus Cerdas Bahasa Indonesia Terbaru. Surabaya: CV Pustaka Agung Harapan.

. M, Sardiman A. 2008. Interaksi Dan Motivasi Belajar Mengajar. Jakarta: PT. Raja Grafindo Persada

Mahfud, Choirul. 2014. The power of syukur . Epistemé, Vol. 9, No. 2, Desember 2014. Diambil dari : http://ejournal.iaintulungagung.ac.id/index.php/epis/article/view/71 (23 Mei 2018)

Nadhiroh , Alfin . 2012. Hubungan Kebersyukuran Dengan Kebermaknaan Hidup Orang Tua Yang Memiliki Anak Autis. Skripsi. Fakultas Psikologi Universitas Islam Negeri Maulana Malik Ibrahim Malang

Najwa , Sakinatun . 2014. Hubungan Konsep Diri Dengan Prokrastinasi Akademik Siswa Kelas XI SMA Al- Rifa’ie Gondanglegi Malang. Skripsi. Fakultas Psikologi Universitas Islam Negeri Maulana Malik Ibrahim Malang Peterson, C \& Seligman, M. E. P. (2004). Character, Strenght, And Virtues: A Handbook \& Classifi Cation. New York: Oxford University press.

Purwanto, Ngalim. 1997. Psikologi Pendidikan. Bandung: PT. Remaja Rosdakarya. Syarbini, Amirulloh. 2012. Buku Pintar Pendidikan Karakter: Panduan Lengkap Mendidik Karakter Anak di Sekolah, Madrasah, dan Rumah. Jakarta: as@ _ prima

Sulistyarini, Ria Indah. 2010. Pelatihan Kebersykuran Untuk Meningkatkan Proactive Coping Pada Survivor Bencana Gunung Merapi. Yogyakarta. Direktorat Penelitian dan Pengabdian Masyarakat Universitas Islam Indonesia 
Shobihah, Ida Fitri. 2014. KEBERSYUKURAN (Upaya Membangun Karakter Bangsa Melalui Figur Ulama). Jurnal Dakwah, Vol. XV, No. 2 Tahun 2014 dambil dari ejournal.uinsuka.ac.id/dakwah/jurnaldakwah/article/download/312/291 （ 22 April 2018)

Sativa, Alissa Rosi dan Helmi, Avin Fadilla. Syukur Dan Harga Diri Dengan Kebahagiaan Remaja. diambil dari : http://jurnalwacana.psikologi.fk.uns.ac.id/index.php/wacana/article/view/9/9 (24 April 2018)

Widyaningsih, Titik Sunarti, dkk.2014. Internalisasi Dan Aktualisasi Nilai-Nilai Karakter Pada Siswa Smp Dalam Perspektif Fenomenologis. Jurnal Pembangunan Pendidikan: Fondasi dan Aplikasi Volume 2, Nomor 2, 2014 diambil dari https://core.ac.uk/display/33511034 ( 19 mei 2018 )

Yayasan Penyelenggara Penerjemah/Penafsir al-Qur'an, Al-Qur'an dan Terjemahnya, Jakarta: Departemen Agama, 2004.

Abidinsyah. "Internalisasi Nilai Peduli Lingkungan Melalui Pembelajaran Berbasis Kearifan Lokal: Studi Di Sdn Antasan Besar 7 Banjarmasin.” Phd, Universitas Pendidikan Indonesia, 2013. http://repository.upi.edu/3700/10/D_PU_0908541_Appendix.pdf.

Ma`arif, Muhammad Anas. "Analisis Strategi Pendidikan Karakter Melalui Hukuman Preventif." Ta'allum: Jurnal Pendidikan Islam 6, no. 1 (6 Maret 2018): 3156. https://doi.org/10.21274/taalum.2018.6.1.31-56.

Ma'arif, Muhammad Anas, dan Salamatu Rochmah. "Target Hafalan Sebagai Motivasi Belajar Dalam Membentuk Karakter Di Lingkungan Pesantren." Muróbbî: Jurnal Ilmu Pendidikan 2, no. 1 (13 Agustus 2018): 105-27.

Ma`arif, Muhammad Anas, dan Muhammad Husnur Rofiq. "The Role of Islamic Education Teachers in Improving the Character of Nationalism in Boarding School." EDUKASI: Jurnal Pendidikan Islam 6, no. 1 (21 Juni 2018): 064078. https://doi.org/10.5281/edukasi.v6i1.323.

Ma'arif, Muhammad Anas. "Analisis Konsep Kompetensi Kepribadian Guru PAI Menurut Az-Zarnuji." ISTAWA 2, no. 2 (2017): 35-60. 